\title{
NEUMAN-SÁNDOR MEAN, ASYMPTOTIC EXPANSIONS AND RELATED INEQUALITIES
}

\section{Neven Elezović AND LENKA VuKŠIĆ}

Abstract. The subject of this paper is a systematic study of inequalities of the form

$$
(1-\mu) M_{1}+\mu M_{3} \leqslant M_{2} \leqslant(1-v) M_{1}+v M_{3}
$$

which cover Neuman-Sándor mean and some classical means. Furthermore, following inequalities with optimal parameters were proved:

$$
\mu \frac{1}{H(s, t)}+(1-\mu) \frac{1}{N S(s, t)} \leqslant \frac{1}{A(s, t)} \leqslant v \frac{1}{H(s, t)}+(1-v) \frac{1}{N S(s, t)}
$$

and

$$
\mu \frac{1}{H(s, t)}+(1-\mu) \frac{1}{N(s, t)} \leqslant \frac{1}{N S(s, t)} \leqslant v \frac{1}{H(s, t)}+(1-v) \frac{1}{N(s, t)} .
$$

Mathematics subject classification (2010): 26E60; 41A60.

Keywords and phrases: Neuman-Sándor mean, asymptotic expansion, optimal convex combination.

\section{REFERENCES}

[1] J. ACZEL, Z. PÁLES, The behaviour of means under equal increments of their variables, Amer. Math. Monthly, 95, (1988), 856-860.

[2] P. S. Bullen, Averages still on the move, Math. Mag., 63 (1990), 250-255.

[3] P. S. Bullen, Handbook of Means and Their Inequalities, Kluwer Academic Publishers, Dordrecht, 2003.

[4] P. S. Bullen, D. S. Mitrinović, P. M. Vasić, Means and theirs inequalities, D Reidel, Dordrecht, 1988.

[5] T. BURIĆ, N. ElEZović, Bernoulli polynomials and asymptotic expansions of the quotient of gamma functions, J. Comput. Appl. Math., 235, 11 (2011), 3315-3331.

[6] T. Burić, N. EleZović, New asymptotic expansions of the gamma function and improvements of Stirling's type formulas, J. Comput. Anal. Appl., 13, 4 (2011), 785-795.

[7] T. Burić, N. Elezović, New asymptotic expansions of the quotient of gamma functions, Integral Transforms Spec. Funct., 23 (2012), 355-368.

[8] T. BuRIĆ, N. ElEZOVIĆ, Approximations of the Euler-Mascheroni constant and harmonic numbers, Appl. Math. Comput., 222 (2013), 604-611.

[9] T. Burić, N. Elezović, Asymptotic expansions of the binomial coefficients, J. Appl. Math. Comput., 46 (2014), 135-145.

[10] C.-P. CHEN, N. ElezoviĆ, L. VuKŠIĆ, Asymptotic expansion of integral mean of polygamma functions Math. Inequal. Appl. 18, 1 (2015), 255-266.

[11] N. Elezović, Asymptotic inequalities and comparison of classical means, J. Math. Inequal., 9, 1 (2015), 177-196.

[12] N. ElEZović, Asymptotic expansions of gamma and related functions, binomial coefficients, inequalities and means, J. Math. Inequal 9, 4 (2015), 1001-1054.

[13] N. ElEZOVIĆ, L. VuKŠIĆ, Asymptotic expansions of integral means and applications to the ratio of gamma functions, Appl. Math. Comput. 235 (2014), 187-200. 
[14] N. Elezović, L. VUKŠIĆ, Asymptotic expansions of bivariate classical means and related inequalities, J. Math. Inequal., 8, 4 (2014), 707-724.

[15] N. Elezović, L. VUKŠIĆ, Asymptotic expansions and comparison of bivariate parameter means, Math. Inequal. Appl., 17, 4 (2014), 1225-1244.

[16] W.-M. Gong, X.-H. Shen, Y.-M. ChU, Bounds for the Neuman-Sándor mean in terms of logarithmic, quadratic or contraharmonic means, Int. Math. Forum, 8, 30 (2013), 1467-1475.

[17] L. Hoenn, I. Niven, Averages on the move, Math. Mag., 58 (1985), 151-156.

[18] W.-D. JIANG, Some sharp inequalities involving reciprocals of the Seiffert and other means, J. Math. Inequal., 6, 4 (2012), 593-599.

[19] D. S. Mitrinović, J. E. PeČArić, A. M. Fink, Classical and New Inequalities in Analysis, D Reidel, Dordrecht, 1993.

[20] E. Neuman, A note on certain bivariate mean, J. Math. Inequal., 6, 4 (2012), 637-643.

[21] E. Neuman, J. SÁndor, On the Schwab-Borchardt mean, Mathematica Pannonica, 14, 2 (2003), 253-266.

[22] Feng QI, We-Hui Li, A unified proof of several inequalities and some new inequalities involving Neuman-Sándor mean, Miskolc Math. Notes, 15, 2 (2014), 665-675

[23] W.-M. QIAN, Y.-M. ChU, On certain inequalities for Neuman-Sándor mean, Abstr. Appl. Anal., 2013, Article ID 790783, 6 pages.

[24] H. Sun, X.-H. Shen, T.-H. Zhao, Y.-M. Chu, Optimal bounds for the Neuman-Sándor means in terms of geometric and contraharmonic means, Appl. Math. Sci., 7, 88 (2013), 4363-4373.

[25] W. XiA, Y. CHU, Optimal inequalities between Neuman-Sándor, centroidal and harmonic means, J. Math. Inequal., 7, 4 (2013), 593-600.

[26] F. Zhang, Y.-M. Chu, W.-M. QIAN, Bounds for the arithmetic mean in terms of the NeumanSándor and other bivariate means, J. Appl. Math., 2013, Article ID 582504, 7 pages.

[27] T.-H. ZhaO, Y.-M. Chu, Y.-L. Jiang, Y.-M. LI, Best possible bounds for Neuman-Sándor mean by the identric, quadratic and contraharmonic means, Abstr. Appl. Anal., 2013, Article ID 348326, 12 pages.

[28] T.-H. Zhao, Y.-M. Chu, B.-Y. LiU, Optimal bounds for Neuman-Sándor mean in terms of the convex combinations of harmonic, geometric, quadratic, and contraharmonic means, Abstr. Appl. Anal., 2012, Article ID 302635, 9 pages. 